DOI: 10.17951/lrp. 2018.37.1.41-54

\author{
JOLANTA ANDRZEJEWSKA
}

Uniwersytet Marii Curie-Skłodowskiej w Lublinie

\title{
ELASTYCZNA PRZESTRZEŃ UCZENIA SIĘ DZIECKA
}

Streszczenie: „Współczesna edukacja przedszkolna w dużej mierze zakotwiczona w starych kodach i paradygmatach coraz częściej nie odpowiada teraźniejszym i przyszłym wyzwaniom. Nie wspiera potencjonalności każdego dziecka w procesie edukacyjnym, nie uwzględnia jego różnic indywidualnych"(Andrzejewska 2015, s. 192).

Tradycyjne rozwiązania edukacyjne, ograniczające się do wykorzystania przez nauczyciela i przedszkolaka najczęściej potencjału sali przedszkolnej i ogrodu, nie podkreślają zagadnień związanych z koniecznością uwzględniania treści edukacyjnych w powiązaniu z kontekstami społeczno-kulturowymi procesów uczenia się. Te konteksty wpływają na proces tworzenia reprezentacji w umyśle i sposób wykorzystania zdobytej wiedzy w odmiennych warunkach. Zatem „ta sama wiedza poznawana w różnych warunkach będzie inaczej »zapisana « w umyśle i inaczej »używana« w nowych sytuacjach (Klus-Stańska, Kruk 2009, s. 471).

Artykuł jest próbą pokazania niewykorzystanych potencjałów sali przedszkola i konieczności rozszerzania przez nauczyciela zasięgu edukacji małego dziecka poza salą przedszkolną, poza przedszkole i kontaktu ze społecznością lokalną, która ze względu na swoją specyfikę i różnorodność warunkuje uelastycznienie procesu uczenia się wychowanka.

Słowa kluczowe: dziecko, edukacja, przedszkole, nauczyciel

\section{WPROWADZENIE}

Namysł nauczycieli przedszkolnych nad racjonalnym wykorzystaniem całej potencjalności przestrzeni edukacyjnej staje się wyzwaniem współczesnej metodyki. Podstawą nowych rozwiązań jest założenie, że niezmiernie ważne dla uczącego się, aktywnego w projektowaniu własnego rozwoju wychowanka jest miejsce, w którym odbywa się jego edukacja oraz uważność nauczycieli odnośnie do wyboru przestrzeni edukacyjnych i ich wykorzystania. 
Zdaniem Jolanty Zwiernik (2009, s. 406) analizującej wyniki badań Rogera G. Barkera „otoczenie tworzy układy przestrzenne, które wydobywają zachowania zgodne z niezwerbalizowanymi zasadami, obligującymi do podejmowania standardowych form aktywności bardziej niż motywacje indywidualne”. Zatem miejsce edukacji staje się odpowiedzialne za każdą zmianę rozwojową dziecka i jego aktywność. Miejsca (sala przedszkolna, korytarze, zakamarki, ogród, boisko, plac zabaw, teren wokół placówki, środowisko lokalne) mają pedagogiczny sens i dzięki nim dziecko zanurza się w kulturze, przyrodzie, gospodarce i świecie relacji społecznych. W miejscach organizowanych przez nauczycieli lub wykorzystywanych przez nich odbywa się budowanie wiedzy przez wychowanków, uzgadnianie znaczeń, tworzenie się systemu wartości, konstruowanie się różnych narracji rzeczywistości. $\mathrm{W}$ przestrzeniach w przedszkolu i poza nim dziecko doświadcza elementów świata przedmiotów, organizuje własną aktywność, współtworzy relacje z rówieśnikami i nauczycielami, powoli dostrzega i odkrywa związki i zależności w otoczeniu oraz określa własne miejsce w złożonym świecie społecznym i wartości.

Miejsca wybrane przez dorosłych i wykreowane przez dzieci pozwalają na zmianę dotychczasowych aktywności, dopuszczają do gromadzenia doświadczeń i umożliwiają badanie rzeczy i zjawisk z innej perspektywy. Uczenie się dziecka jest możliwe i ustalone w danym miejscu przez określony zbiór elementów i relacji społecznych. „Kategoria miejsca może bowiem stymulować, wspierać procesy interpretacji i twórczej reprezentacji." (Wiśniewska-Kin 2015, s. 23).

„Porządek społeczny jest wypadkową zwykłych działań ludzi, którzy w toku swej aktywności wywołują bieg rzeczywistości społecznej, nadając jej zarazem pedagogiczny sens" (Szymański, Walasek- Jarosz, Zbróg 2016, s. 15). Czynnikiem hamującym rozwój dziecka może być sam nauczyciel, który w swych codziennych czynnościach nie dostrzega i nie wykorzystuje potencjału miejsc, w których przebywa i w których mógłby być $\mathrm{z}$ dziećmi. Nadal w niewielkim stopniu akcentowana jest w metodyce przedszkolnej interakcja, jaka zachodzi między dzieckiem i miejscem, w którym przebywa, interakcja dziecka $\mathrm{z}$ rówieśnikami i kreowanymi przez nie miejscami. Trudności dostarcza także uwzględnianie przez nauczyciela wielu innych elementów często sprzecznych ze sobą związanych z instrumentalną dydaktyką.

Miejsca oprócz potencjału rozwojowego mogą nieść za sobą niebezpieczeństwa: fizyczne - związane z urazami ciała, społeczne - powiązane z kontaktem dzieci z zagrażającymi osobami i kulturowe - powiązane z osiągnięciami cywilizacyjnymi np. z mediami, konsumpcjonizmem. Zdaniem Moniki Wiśniewskiej-Kin (2015, s. 25) „pedagog animator miejsca ma obowiązek świadomie ingerować w obszary będące zagrożeniem dla uczniowskiej tożsamości”. Jak twierdzi Maria Mendel, „o miejsca toczy się walka, miejsca są okupowane" (Mendel 2006, s. 271), a różnorodne konteksty społeczne, kulturowe, ekonomiczne, gospodarcze, edukacyjne sprawiają, 
że wychowankowie w różnorodny sposób korzystają z oferowanych przez nauczycieli przestrzeni edukacyjnych (Dahlberg, Moss, Pence 2013). Proponowana przez Michaela Foucaulta (1998) refleksja nad władzą w ogóle, w tym także władzą nauczycielską, zmusza do refleksji nad kategorią skutków określonych praktyk edukacyjnych wprowadzanych przez pedagogów. Następstwa mogą również dotyczyć niewłaściwego zarządzenia miejscami, w których odbywa się edukacja dzieci.

\section{NAUCZYCIEL-ANIMATOR MIEJSC}

Nauczyciel, projektując miejsca uczenia się wychowanków, uwzględnia wiele elementów. Dla współczesnego praktyka oświatowego nie jest łatwo zaprojektować i wybrać miejsca, które zainspirują wychowanków i przyczynią się do rozwinięcia ich potencjału, czyli ich „predyspozycji, uzdolnień, zainteresowań, potrzeb, preferencji, artykułowanych marzeń, planów, możliwości rozwojowych, ukrytych zalążków przyszłych aktywności" (Kubinowski 2016, s. 100).

Nauczyciel przedszkola jako animator miejsc do uczenia się ma za zadanie:

- pobudzić dziecko do różnorodnych działań;

- wnosić coś nowego do procesu jego rozwoju;

- dodawać sił i inspiracji do działania;

- zapoczątkowywać nowe przedsięwzięcia i zabawy;

- dodawać do istniejącego środowiska impulsy rozwojowe.

Wychowawca w pracy nie tylko dynamizuje działania poszczególnych dzieci, ale i przez inspiracje i znoszenie blokad (m.in. społecznych, edukacyjnych, poznawczych, ekonomicznych), ograniczeń pobudza i ożywia działanie zespołów, np. zabawowych lub badawczych dzieci lub całej grupy przedszkolnej. Działania nauczyciela-animatora dodającego odwagi, wzmacniającego kreatywność i decyzyjność przedszkolaków mogą zainspirować wychowanków do zgłaszania nowych inicjatyw, kreacji sytuacji edukacyjnych tworzonych „od dzieci” i z ich perspektywy.

Nauczyciel-animator miejsc ma również zmieniać i stymulować społeczności lokalne do:

- działań wspólnotowych, zaniechanych inicjatyw lub oddolnych projektów (Kubinowski 2016, s. 97),

- twórczego działania,

- realizowania nowych przedsięwzięć, pomysłów, perspektyw na rzecz uczenia się dzieci,

- odkrywania w sobie sił twórczych (Kargul 1995, s.93), zachowań ekspresyjnych. 
Ważną rolą nauczyciela-animatora miejsc jest „ułatwienie komunikacji międzyludzkiej oraz inicjowanie życia kulturalnego i społecznego" (Dąbrowska 1989, s. 104).

Nauczyciel ma odkryć potencjał konkretnego miejsca, wspólnoty lokalnej oraz zaktywizować dziecko w tej przestrzeni edukacyjnej. Czasem nie musi tego miejsca zmieniać, kreować, niekiedy wystarczy je naznaczyć za pomocą różnych komunikatów, wydobyć z całości przestrzeni przedszkola lub środowiska lokalnego, wypromować nową funkcję miejsca. Nauczyciel-animator miejsca ma prowadzić metodykę niedyrektywną, oferującą, dopasowaną do kontekstu społecznego i osobowego, „bliską podejściom elastycznym, empatycznym, kreatywnym, adekwatnym” (Kubinowski 2016, s. 100).

Nauczyciel, kreując przestrzeń, najpierw powinien przeanalizować jej przesłanki edukacyjne tak, aby wychowankowie nie poczuli się pokrzywdzeni, wykluczeni, zmarginalizowani i niedocenieni. Przedmiotem analiz podstaw edukacyjnych powinna być:

1. współczesna definicja dziecka jako podmiotu aktywnego i sprawczego,

2. rola doświadczeń w procesie uczenia się,

3. rola problemów rozwiązywanych przez dzieci powiązanych $\mathrm{z}$ interdyscyplinarnie ujętymi treściami programowymi,

4. możliwość dokonywania przez dzieci egzemplifikacji w szerokich kontekstach edukacyjnych.

\section{DEFINIOWANIE DZIECKA}

We współczesnych koncepcjach konstruktywizmu poznawczego i społecznokulturowego dziecko jest autonomicznym, aktywnym podmiotem poznającym (Gopnik 2010), przez doświadczenia buduje w umyśle wiedzę o sobie i świecie (Dylak 2010), ma moc sprawczą i poczucie sprawstwa, charakteryzuje się wolnością i możliwością wyboru, jest aktywne w zabawie, nauce i pracy (Davies, Braun 2006) oraz ma indywidualne linie rozwojowe. Aktywność jest czynnikiem wpływającym na morfologiczną oraz funkcjonalną zmianę mózgu. Podczas opracowania każdego pojęcia potrzebna jest dziecku wieloraka działalność oparta na aktywności fizycznej, teatralnej, tanecznej, muzycznej. Zatem miejsca, które wybiera nauczyciel przedszkola, powinny umożliwiać dziecku podejmowanie każdej aktywności w sali przedszkolnej, w ogrodzie przedszkolnym, w ośrodkach kultury, obiektach sportowych, teatrach.

Dziecko zdaniem konstruktywistów ma odkrywać świat i samego siebie w różnych relacjach ze światem. Dlatego rolą nauczyciela jest tworzenie warunków do tego, aby każda grupa przedszkolna i każda jednostka w przedszkolu mogła ujawnić 
potrzeby, problemy, wątpliwości, pragnienia. Proces ten m.in. może dokonać się przez styczność dzieci z miejscami wybranymi, zaaranżowanymi przez wychowawców. Dziecko w procesie uczenia się tworzy w umyśle związki (organizuje stosunki). Przemyślana przestrzeń edukacyjna wpływa na kształtowanie się kontaktów dzieci zarówno między sobą, jak i z pracownikami przedszkola i oferowanym światem kultury oraz natury. W wyniku relacji opartych na wzajemnym zrozumieniu i porozumieniu rodzą się doświadczenia i nowe kreacje dzięki „sprzężeniu jednostek i grup z otoczeniem poprzez ekspresję, inicjatywę, odpowiedzialność i działania twórcze" (Jedlewska 1999 s. 56).

\section{ROLA DOŚWIADCZEŃ}

Intensywne doświadczenia dzieci implikują formowanie trwałych zmian w mózgu (Dylak 2013), dlatego wychowankowie potrzebują wsparcia „mądrego dorosłego”, aby działać w strefie najbliższego rozwoju i gromadzić doświadczenia. Intensywne doświadczenia łączą się z miejscami istotnymi dla dziecka, nowymi, nieoczekiwanymi. Takie miejsca znajdzie nauczyciel w przedszkolu: w kącikach zainteresowań, zakamarkach, kuchni, pracowni konserwatora, gabinecie dyrektorki, sali doświadczania świata, ścieżkach sensorycznych zlokalizowanych na korytarzach, na schodach przedszkolnych $\mathrm{z}$ zaprojektowanymi zdaniami, w zakamarkach do relaksu oraz marzeń i wyobraźni, minizwierzyńcach z rybkami, ptakami i żółwiami lub pachnących ziołowych ogródkach na holach przedszkolnych. Duży wachlarz intensywnych doświadczeń dzieci zdobędą podczas pobytu w miejscach lokalnych m.in. w bibliotekach, zakładach usługowych (szewca, optyka, krawcowej, fotografa, kowala), zakładach produkcyjnych, sklepach spożywczych i specjalistycznych (mydlarni, z artykułami żelaznymi), ośrodkach kultury, urzędach. Dziecięce doświadczenia także tworzą się w kontakcie z naturą podczas outdoorowej edukacji:

- na terenie przy przedszkolu (boisko, plac zabaw, ogród, trawnik, niezagospodarowany teren),

- w lokalnym sąsiedztwie przedszkola (skwer, duże drzewo),

- w dalszej przestrzeni: na łące, wrzosowisku, w lesie, parku, zoo, ogrodzie botanicznym, arboretum, nad stawem, rzeką, jeziorem, morzem, na plaży, przy kałuży, w parku narodowym, przy pomniku przyrody ożywionej lub nieożywionej.

„Dzieci powinny mieć możliwość bycia z przyrodą" (Korwin-Szymanowska, Lewandowska 2015, s. 69), ponieważ tworzenie więzi z naturą możliwe jest wyłącznie przez przebywanie i odkrywanie środowiska naturalnego o różnych porach 
dnia, roku, w różnych warunkach atmosferycznych, w czasie różnych zdarzeń (np. odlot ptaków, migracja zwierząt).

Nauczyciel, projektując miejsce do ucznia się dzieci i gromadzenia nowych doświadczeń w terenie, powinien uwzględnić to, co może ono zaoferować dzieciom. Listę przydatności środowiska zewnętrznego do przyrodniczych zajęć przytaczają za Marjorie Ouvry (2003) Adamina Korwin-Szymanowska i Ewa Lewandowska (2015, s. 72). Nauczyciel, analizując miejsce, zwraca uwagę, czy dzieci będą miały możliwość:

- obserwowania roślin i zwierząt,

- pobrania próbek materiałów,

- obserwacji zbiorników wodnych,

- doświadczania faktur, zapachów, dźwięków (Andrzejewska, Lewandowska 2008, s. 5-6),

- podejmowania aktywności fizycznej,

- poznawania rozmiarów, kształtów, różnorodności barw i odcieni,

- podejmowania aktywności pobudzającej wyobraźnie i wrażliwość na piękno i harmonię (Andrzejewska, Lewandowska 2009, s. 155-159),

- tworzenia sztuki z naturalnych materiałów.

\section{ZNACZENIE ROZWIĄZYWANIA PROBLEMÓW PRZEZ DZIECI}

Współczesne badania dowodzą, że dzieci nie są bezradne podczas rozwiazywania problemów i od początku zmagają się z nimi w codziennym życiu. Daphna Buchsbaum, Thomas L. Griffiths, Alison Gopnik, Patrick Shafto (2011) wykazują, że dzieci uczą się przez podejmowanie decyzji odnośnie do naśladowania całości lub sekwencji działania $w$ wielokrotnie powtarzanych sytuacjach w określonych miejscach. Laura E. Schulz (2007, s. 322) twierdzi, że „dzieci są w stanie wykorzystać wiedzę o strukturze przyczynowej i przewidzieć wzory dowodów, które mogłyby wyniknąć z interwencji”. Dzieci w odpowiednio zorganizowanych przestrzeniach/ laboratoriach przedszkolnych i poza nimi potrafią:

- zdobywać wiedzę jak naukowcy przez eksperymenty;

- przeprowadzać doświadczenia;

- wnioskować statystycznie;

- określać przyczynę i skutek zdarzenia;

- analizować i rozumieć podstawowe zjawiska fizyczne, takie jak ruch, grawitacja, zawieranie się;

- rozpoznawać regularności w seriach tonów muzycznych, obrazkach i wzorach geometrycznych, elementach przyrody czy architektury;

- poznawać zasadę działania urządzeń i zasady życia społecznego. 
Podczas zabawy swobodnej, konstrukcyjnej, tematycznej, badawczej, dydaktycznej, heurystycznej w inspirujących miejscach (m.in. ogrodzie przedszkolnym, kącikach teatralnych, przedszkolnych zakamarkach, kącikach historii i tradycji, zawodów rodziców, badań naukowych) stosują najskuteczniejsze sposoby odkrywania reguł funkcjonowania świata (Devies, Braun 2006). Problemy, z jakimi spotykają się wychowankowie, muszą mieć określoną strukturę i naturę. $\mathrm{W}$ razie problemu przekraczającego możliwości jednego dziecka nauczyciel tworzy zespoły rówieśników, które zmagają się z nim lub sam udziela wsparcia.

\section{DZIECIĘCE EGZEMPLIFIKACJE}

Proponowane przez nauczycieli miejsca i sytuacje edukacyjne pomagają dzieciom w użyciu różnych „narzędzi” kulturowych. Ważny najpierw jest sam proces uczenia się, a dopiero potem jego efekt. Uczenie się przez zakotwiczenie w określonych kontekstach i efektywne opracowanie informacji pozwala na późniejsze efektywne, samodzielne wykorzystanie przez dziecko wiedzy. Uczenie się to proces aktywny, w którym uczący się tworzy nowe idee albo pomysły na bazie swojej przeszłej i obecnej wiedzy w określonym miejscu. Dziecko przez cały czas pobytu w przedszkolu i w drodze do niego przetwarza różnorodne informacje, selekcjonuje je, stawia i weryfikuje hipotezy oraz podejmuje decyzje (Wollman 2013).

Nauczyciel przedszkola oprócz wyboru miejsca powinien zadbać o równowagę między zadaniami ukierunkowanymi na cel a uczniem się okazjonalnym dzieci w danym miejscu. Podczas określania potencjału miejsca powinien wykazać się gotowością na zdarzenia, które trudno przewidzieć, na dostrzeżenie przez wychowanków perspektyw nieoczywistych dla dorosłych. W takich miejscach przy odpowiedniej ilości czasu i tolerancji dziecięcych aktywności wychowankowie dążą do tworzenia wniosków, uogólnień, odkrywania prawidłowości, powtarzalności, przyczynowości (Andrzejewska 2013).

W środowisku lokalnym możliwa jest egzemplifikacja wiedzy naukowej zdobytej w przedszkolu. Stąd do wachlarza miejsc można zaliczyć architekturę miasta (przejścia dla pieszych, krawężniki i chodniki, mosty, słupy wysokiego napięcia, trakcje trolejbusów lub tramwajów, przystanki autobusowe, stacje metra, szyldy sklepów, półki sklepowe z nazwami towarów i znaki drogowe, które pozwolą m.in. wychowankom pochwalić się dzieciom umiejętnością odczytywania piktogramów i innych kodów) (Andrzejewska 2015). Analiza przydatności miejsca na dziecięce egzemplifikacje ma dotyczyć także możliwości posługiwania się narzędziami, np. lupą, nożyczkami, pęsetą, lornetką, szczypcami, pudełkiem na materiał, sprzętem 
fotograficznym, dziennikiem badacza/notatnikiem, ołówkiem, plecakiem (Lewandowska, Korwin-Szymanowska 2015, s. 88).

Nauczyciel traktujący rodziców jako partnerów edukacji dziecka uwzględnia możliwości rodziny przeniesienia wiedzy i umiejętności dzieci do nowych przestrzeni. Dlatego ważne jest systematyczne (około dwa razy w tygodniu) zadawanie dzieciom „domowniczka” (Andrzejewska 2016). Są to specyficzne zadania możliwe do wykonania jedynie z rodzicami, rodzeństwem lub dziadkami. Takie zadania mogą dotyczyć: wykonania zdjęć/filmu „super nosów” podczas spacerów z rodziną, przygotowania herbu rodziny z materiałów przyrodniczych, wykonania zabawki-dinozaura ze starej skarpety, zebrania bukietów kwiatów do przedszkola, policzenia $\mathrm{z}$ dziadkami urządzeń działających na prąd w domu, pokazania rodzeństwu, jak się robi łódkę z origami. „Domowniczki” nie tylko łączą oba środowiska, w których odbywa się edukacja dziecka, ale pozwalają utrwalać wiedzę i umiejętności, budować poczucie sprawstwa i podnosić samoocenę dzieci.

\section{PROJEKTOWANIE MIEJSC DO UCZENIA SIĘ DZIECI}

Inspiracje do rozwiązań praktycznych zaczerpnęłam $\mathrm{z}$ badań prowadzonych w latach 2011-2017. W badaniach wykorzystałam obserwację zachowań dzieci (rodzaje podejmowanych aktywności) i ich spontaniczne wypowiedzi (komentarze na temat zastanej rzeczywistości) ujawniane w społecznych praktykach, zaangażowanie społeczności lokalnej podczas współrealizacji 15 projektów edukacyjnych w przedszkolach o tematyce: „Mydło najlepsze dla przedszkolaka”, „Tęczowy świat”, „Plecak podróżnika”, „Mieszkańcy łąki”, „Światło”, „Kosmos”, „Żywioły. Ogień. Ziemia. Woda”, „Ptaki”, „Badacze jajka”, „Mleko” „Maszyna prosta”, „Tropiciele zapachów”, „Fizyka, technika i chemia w przedszkolu”, „Boże Narodzenie - dziecko w świecie wartości i tradycji”, „Moje miasto”.

Zaprezentowane $\mathrm{w}$ dalszej części artykułu rozważania nie pretendują do wyczerpania oglądu tego zagadnienia. Są jedynie inspiracją dla nauczycieli do prowadzenia obserwacji i animacji nowych miejsc w przedszkolu i poza nim.

\section{ROZWIĄZANIA PRAKTYCZNE}

Projektowanie edukacji w grupie przedszkolnej związane jest z decyzją wyboru określonego myślenia/dyskursu edukacji. Dorota Klus Stańska (2009, s. 55-74) wyróżnia następujące jego odmiany w obszarze wczesnej edukacji: dyskurs funkcjonalno- 
-behawioralny, humanistyczno-adaptacyjny, konstruktywistyczno-rozwojowy, konstruktywistyczno-społeczny, krytyczno-emancypacyjny.

W przypadku, gdy nauczyciel w swojej drodze zawodowej opowiada się za konstruktywizmem poznawczym i społeczno-kulturowym, to wyznacza sobie i wychowankom organizację przestrzeni edukacyjnej opartej m.in. na różnicach indywidualnych dzieci, podmiotowości, autonomii, samodzielności, dużej roli interakcji dziecka z rówieśnikami, nauczycielem i ekspertami.

Projektowanie miejsc do uczenia się wspólnotowego/w zespołach dzieci nauczyciel rozpoczyna od analizy wartości zawartych w treściach programowych ułożonych interdyscyplinarnie lub mapach pytań w projektach edukacyjnych. Nauczyciel następnie robi mapę miejsc i ich potencjalnej możliwości wykorzystania podczas realizacji określonego tematu/projektu. To oczywiste, że inne miejsca będą ważne dla nauczyciela i przedszkolaków w projekcie „Tropiciele zapachów”, a inne w projekcie „Maszyna prosta”.

Analiza przestrzeni edukacyjnej dotyczy kilku obszarów:

- sali przedszkolnej,

- pomieszczeń w przedszkolu poza salą przedszkolną,

- środowiska na zewnątrz typu ogród przedszkolny, plac zabaw, droga do placówki,

- środowiska na zewnątrz typu środowisko lokalne: instytucje użyteczności publicznej, społeczności, stowarzyszenia, zakłady pracy.

Nauczyciel zastanawia się, jaki jest potencjał miejsc i co, kiedy, w jakiej kolejności może podbudzić pojedyncze dziecko i zespół przedszkolaków, którzy uczą się od siebie i wspólnie konstruują znaczenia. Wychowawca wie, że ma wydobyć z całości przestrzeni przedszkola lub środowiska lokalnego elementy, które będą sprzyjały indywidualnym liniom rozwojowym dzieci.

Nauczyciel przedszkola przyjmuje złożenie, że przestrzeń jest elastyczna, czyli można ją dowolnie zmieniać, aranżować, prezentować. Obserwacja poszczególnych dzieci i zespołów badawczych lub zabawowych w działaniu w kontakcie z przestrzenią pozwala nauczycielowi na zarządzenie czasem i miejscami na kreacje, potrzeby, nowe pytania dzieci.

\section{SALA PRZEDSZKOLNA JAKO UKŁAD PRZESTRZENNY}

Współczesny nauczyciel przedszkola powoli odrzuca stary paradygmat urządzenia sali przedszkolnej, promuje nową funkcję tego miejsca, aranżuje nowe umeblowanie i tworzy salę przedszkolną i inne pomieszczenia w placówce na kształt elastycznego laboratorium lub ośrodka edukacyjnego, w których autonomiczne, 
aktywne dzieci wspólnie uczą się, bawiąc się, rozwiązując problemy, wykonując zadania, tworząc własne rozwiązania.

Zdaniem Petera Mossa, Alana Pence’a i Gunilli Dahleberg (2013) przedszkole powinno być przestrzenią słuchania i dyskusji, stwarzającą możliwość rzeczywistego zaangażowania i zmiany. Bogactwo układów przestrzennych w sali przedszkolnej, jakość kontaktów wpływają na zadowolenie z życia, szerokości i jakości stosunków społecznych, odporność organizmu, rozwój sił twórczych.

Każdorazowo przestrzeń sali staje się naznaczona przez nauczyciela, za pomocą różnych komunikatów, główną ideą/wartością. Tę wartość mają odkryć i pracować nad nią wychowankowie przy pomocy różnych narzędzi intelektualnych. Idea jest najczęściej ściśle powiązana z treściami tygodnia (w edukacji klasycznej) lub pytaniami dzieci pojawiającymi się w sytuacji problemowej (w metodzie projektów). W przypadku projektu „Mydło najlepsze dla przedszkolaka” okolicznością, która zapoczątkowała działania dzieci, była sytuacja braku mydła w dziecięcej łazience. Przedszkolaki poinformowały nauczycielkę, że skończyło się mydło, a ona zamiast mechanicznie przynieść nowe, spytała, jakie mydło jest dla nich najlepsze. Wtedy padły różne propozycje, które otworzyły drogę do działań badawczych związanych z cechami mydła, jego koloru, konsystencji, sposobu pienienie się, wielkości i kształtu pojemnika, a na samym końcu jego cenie. Po dokonaniu przez dzieci odkrycia głównego problemu zaczynają się czynności eksploracyjne. Wtedy sala przedszkolna jest skazana na nieustanne przekształcenia w umeblowaniu, rozmieszczeniu kącików i aranżacji pomocy dydaktycznych lub zabawek.

Czynnikiem wpływającym na zmianę wyglądu sali i jej kącików: badacza, odkrywcy, patrioty i obywatela, konstruktora, tradycji, książki i wiedzy, marzeń i wyobraźni, muzyki, teatru, ekspresji plastycznej jest problematyka. W tematach tygodnia zawarte są wartości, do których w prowadzane jest dziecko (np. wartości estetyczne - temat tygodnia "Gdzie ukryła się muzyka”, wartość planowania życia - „Jesienna domowa spiżarnia”, pomoc innym - „Zwierzęta przygotowują się do zimy"). Nauczyciel, aranżując miejsca, stale wnosi do nich coś nowego, ważne, aby elementy były ściśle powiązane z problematyką i nie pojawiały się „rozpraszacze” dziecięcej uwagi.

Zamianę aranżacji sali warunkuje również wiedza dzieci. Na początku projektów, gdy wiedza osobista dzieci jest mniejsza, wystarczą umieszczone w sali drobne elementy zaciekawiające dzieci do aktywności poznawczej, badawczej. W miarę zanurzania się przedszkolaków w problematykę, pojawiania się pytań dziecięcych, „drążenia przez nie problemów” sala przekształca się w bogate laboratorium z wieloma źródłami wiedzy na precyzyjnie określone tematy.

Stworzenie w dzieciach konfliktu poznawczego, zaciekawienia określonym tematem to kolejny czynnik zmieniający wygląd sali. Duże znaczenie w tym 
względzie odgrywa „pustka”. W analizowanych projektach dzieci na początku były zaskakiwane wyglądem sali, z której wyniesiono wszystkie zabawki, pozostawiając jedynie:

- meble przedszkolne, nowe „dorosłe fotele” do czytelnia i oglądania książek,

- kącik książki i wiedzy (np. w kurniku),

- napisy i obrazki związane z tematyką badacza, np. jajek,

- materiały plastyczno-konstrukcyjne (kartony, plastikowe butelki, miseczki, pojemniki po różnych produktach, tkaniny...).

Zmiana sali przez krótką chwilę zadziwiała dzieci, szczególnie trzylatków. Przedszkolaki bardzo szybko znajdowały strategie adaptacyjne m.in.: wspólnej zabawy w bieganie z grupą rówieśników, zabawy swobodnej z małą ilością rekwizytów, zabawy w udawanie, np. moczenie nóg w pustej misce, zabawy heurystycznej z wykorzystaniem materiałów plastyczno-konstrukcyjnych, np. zabawa w dinozaury - drugie życie skarpety, rozmowy przy książkach powiązanych wyłącznie z tematem (np. „Jajko”), pogawędki z nauczycielem na temat tego, o czym będą się uczyły w tym tygodniu, zabawy odkrywców napisów i kodów znajdujących się w sali.

Kolejną przyczyną zmiany potencjału sali przedszkolnej jest zaangażowanie dzieci, rodziców i społeczności lokalnej, która wchodząc w projekt edukacyjny, wypromowany przez dyrektora przedszkola i radę pedagogiczną, dostarcza nowych pomocy dydaktycznych. Poziom zaangażowania środowiska proporcjonalnie zwiększa atrakcyjność poznawczą przedszkola. Środowisko lokalne może mieć większy i mniejszy potencjał edukacyjny. Zależy to od ilości instytucji znajdujących się w środowisku i ich dostępności dla aktywnych podmiotów.

Środowisko nawet o dużym nasyceniu instytucjami i elementami przyrodniczymi nie będzie stanowiło dla dziecka wartości i nie będzie stwarzało warunków do uczenia się do momentu aż nauczyciel nie nada mu znaczenia. Dlatego nauczyciele-animatorzy środowiska zaangażowani w uczenie się dzieci aktywizują całą społeczność.

Zmotywowana w projektach społeczność dostarcza nieosiągalne przez nauczycielki:

- pomoce dydaktyczne (np. mundur leśnika, lornetki, pojemniki na wodę, wymontowane lampy samochodowe, narzędzia ogrodnicze),

- książki z rodzinnych biblioteczek,

- żywe okazy (kury, gołębie, węże, pawie),

- przedmioty o znaczeniu historyczny (pamiątki rodzinne).

Otoczenie społeczne angażuje się osobiście, opowiadając dzieciom o swoich pasjach, zawodach i doświadczeniach lub pozwalając dotrzeć do miejsc niedostępnych, np. oglądanie maszyn rolniczych i zwierząt we własnym gospodarstwie, odwiedziny w gabinecie burmistrza. 
Salę przedszkolną zmieniają także same dzieci. Ich aktywność zabawowa i nieograniczona wyobraźnia tworzą z sali warsztaty artystów, architektów i badaczy rzeczy ważnych. Gdy nauczyciel pozwoli, przez zaplanowanie czasu i wyposażenie sali, na dziecięce kreacje, to może zaobserwować cały potencjał wychowanków, który jedynie jest dany, gdy dzieci nie są krępowane systemem wymyślonym przez dorosłych, związanym ze sztywną organizacją posiłków, nadmiarem zajęć dodatkowych i przygotowań do uroczystości lub konkursów.

\section{PODSUMOWANIE}

Zdaniem Doroty Klus-Stańskiej (2010) sposób konstruowania nowych znaczeń lub rekonstruowania dotychczasowych decyduje o możliwych sposobach ich używania w przyszłości. Zatem doświadczenie przez przedszkolaków różnorodnych kontekstów poznawczo-społecznych w trakcie pobytu w bogatych miejscach w przedszkolu i poza nim wpływa na jakość wiedzy w przyszłości.

\section{LITERATURA}

Andrzejewska J., Lewandowska E., 2008, Kreowanie aktywności ucznia. „Życie Szkoły”, nr 2, 5-8.

Andrzejewska J., Lewandowska E., 2009, Nauczyciel - kreator przestrzeni i czasu szkolnego. W: K. Kusiak, I. Nowakowska- Buryła, R. Stawinoga (red.), Edukacyjne konteksty rozwoju dziecka $w$ wieku wczesnoszkolnym. Lublin, Wydawnictwo UMCS, 155-159.

Andrzejewska J., 2013, Zróżnicowanie modeli edukacyjnych w przedszkolu a funkcjonowanie psychospołeczne dzieci. Lublin, Wydawnictwo UMCS.

Andrzejewska J., 2015, Oferta edukacyjna przedszkola a kompetencje społeczne dzieci. W: J. Uszyńska-Jarmoc, K. Nadachewicz (red.), Kompetencje kluczowe dzieci i młodzieży. Praktyka edukacyjna. Warszawa, Wydawnictwo Akademickie Żak.

Andrzejewska J., 2015, Przestrzeń przedszkola przyjazna ksztattowaniu gotowości dziecka do nauki czytania i pisania. „Roczniki Pedagogiczne”, t. 7(43), nr 2.

Andrzejewska J., 2016, Partnerstwo przedszkola, rodziny i społeczności lokalnej w metodzie projektów. „Scientific Bulletin of Chełm: Section of Pedagogy”, nr 2, 89-106.

Buchsbaum D., Gopnik A., Griffiths T.L., Shafto P., 2011, Children's Imitation of Causal Action Sequences Is Influenced by Statistical and Pedagogical Evidence. "Cognition" 120, 331-340 [pozyskano z: http://scholar.berkeley.edu/daphnab/files/ buchsbaum-gopnik-griffiths-shafto-cognition.pdf]. 
Dahlberg G., Moss P., Pence A., 2013, Poza dyskursem jakości w instytucjach wczesnej edukacji i opieki. Wrocław, Wydawnictwo Dolnośląska Szkoła Wyższa.

Davies R.D., Braun E.M., 2006, Dar uczenia się. Poznań, Wydawnictwo Zysk i S-ka. Dąbrowska E., 1986, Analiza sytuacji animacyjnych. „Pedagogika Pracy Kulturalno-Oświatowej”, nr 7, 103-104.

Dylak S., 2013, Architektura wiedzy w szkole. Warszawa, Wydawnictwo Dyfin.

Foucault M., 1998, Nadzorować i karać. Narodziny więzienia. Warszawa, Fundacja Aletheia. Gopnik A., 2010, Jak myślą dzieci?. „Świat Nauki”, nr 8, 44-49.

Jedlewska B., 1999, Animatorzy kultury wobec wyzwań edukacyjnych. Lublin, Wydawnictwo UMCS.

Kargul J., 1995, Od upowszechniania kultury do animacji kulturalnej. Toruń, Wydawnictwo Adam Marszałek.

Kargul J., 2012, Upowszechnianie, animacja, komercjalizacja kultury. Warszawa, PWN. Korwin-Szymanowska A., Lewandowska E., 2015, Projektowanie i ewaluacja zajęć przyrodniczych w klasach początkowych. W: A. Korwin-Szymanowska, E. Lewandowska, L. Tuszyńska (red.), Edukacja środowiskowa w kształceniu nauczycieli w perspektywie praktycznej. Warszawa, Wydawnictwo APS, 37-81.

Kubinowski D., 2015, Istota animacji kultury jako idei pedagogicznej. „Studia Kulturowo-Edukacyjne", t. X, nr 1.

Kubinowski D., 2001, Zasada konstruktywnego relatywizmu jako podstawa aksjologiczna działalności animacyjnej: perspektywa antropologiczno-pedagogiczna. W: J. Gajda, W. Żardecki (red.), Dylematy animacji kulturalnej. Lublin, Wydawnictwo UMCS. Kubinowski D., 2016, Kultura animacji jako humanistyczna pedagogia. „Nauki o Wychowaniu. Studia Interdyscyplinarne", nr 2(3).

Lewandowska E., Korwin-Szymanowska A., 2015, Terenowe zajęcia przyrodnicze w klasach początkowych - propozycje zajęć. W: A. Korwin-Szymanowska, E. Lewandowska, L. Tuszyńska (red.), Edukacja środowiskowa w kształceniu nauczycieli w perspektywie praktycznej. Warszawa, Wydawnictwo APS.

Mendel M., 2006, Pedagogika miejsca. Wrocław, DSWE TWP.

Schulz L.E., Gopnik A. Glymour C., 2007, Preschool Children Learn About Causal Structure from Conditional Interventions. "Developmental Science”, pp 322-332, 3. Szymański M.J., Walasek- Jarosz B., Zbróg Z., 2016, Zrozumieć szkołę dla (jej) zmiany. W: M.J. Szymański, B. Walasek-Jarosz, Z. Zbróg (red.), Zrozumieć szkołę. Konteksty zmiany. Warszawa, APS.

Wiśniewska-Kin M.,2015, Kompetencje kluczowe uczniów w społeczeństwie wiedzy konieczność mentalnych przewartościowań. W: J. Uszyńska-Jarmoc, K. Nadachewicz (red.), Kompetencje kluczowe dzieci i młodzieży. Praktyka edukacyjna. Warszawa, Wydawnictwo Akademickie Żak. 
Wollman L., 2013, Rozwijanie potencjału uczenia się w społecznej przestrzeni edukacji, Katowice, Wydawnictwo SNEP.

Zwiernik J., 2009, Dziecięca codzienność w przestrzeniach podwórka. W: D. Klus-Stańska, M. Szczepkowska-Pustkowska (red.), Pedagogika wczesnoszkolna - dyskursy, problemy, rozwiąania. Warszawa, Wydawnictwa Akademickie i Profesjonalne.

\title{
FLEXIBLE LEARNING SPACE OF THE CHILD
}

\begin{abstract}
Contemporary pre-school education, largely anchored in old codes and paradigms, increasingly does not correspond to current and future challenges. It does not support the potential of every child in the educational process, does not take into account his individual differences" (Andrzejewska 2015, p. 192).

Traditional educational solutions, mainly limited to the use of the potential of the kindergarten classroom and the garden by teachers and pre-schoolers, do not emphasise the issues connected with the need to include educational content linked with the socio-cultural contexts of learning processes. These contexts influence the process of representation in the mind and the way of using the knowledge acquired in different conditions. Thus, "the same knowledge learned in different conditions will be differently 'written' in the mind and differently 'used' in new situations” (Klus-Stańska, Kruk 2009, p. 471).

The article is an attempt to show the unused potentials of the kindergarten classroom and the need for the teacher to extend the range of education of the pre-schooler outside the classroom, outside the kindergarten to the local community, which due to its specificity and diversity conditions greater flexibility of the learning process.
\end{abstract}

Keywords: child, education, kindergarten, teacher 